\title{
SUSTAINABLE AGRICULTURAL PRACTICES AND RELATED PROBLEMS AMONG RICE FARMING HOUSEHOLDS IN KWARA STATE, NIGERIA
}

\author{
K.K. OSASONA ${ }^{1^{*}}$, G.B. AKINSOLA ${ }^{1}$, M.F. SALAMI ${ }^{1}$, L.O. ADEBISI ${ }^{1}$, \\ O.A. ADEBISI ${ }^{1}$, O. FASHOLA ${ }^{1}$ \\ *E-mail: okennieegreat@gmail.com
}

Received: Jan. 17, 2020. Revised: Feb. 13, 2020. Accepted: Feb. 20, 2020. Published online: Mar. 06, 2020

\begin{abstract}
Farmers in Nigeria are unpredictable unlike other developing countries where a good agronomic practices are used for a sustainable increase in rice production as result, the demand for rice consumption far overweighs rice production. This study presented empirical findings on the sustainable agricultural practices and its constraints among the rice farming households in one selected state of Nigeria. The study utilized primary data collected in 2019 using a four stage random sampling techniques. A total sample of 150 rice farmers was collected with the use of descriptive statistics, Likert-type scale and multinomial logistic regression model for analysis. The result indicates that the recommended sustainable agricultural practices (SAP) least adopted were the use of High Yielding Variety seed and agrochemicals probably due to their high cost. The factors that influences the full usage of SAP in rice farming were farm size, level of education, farming experience, extension contact and access to credit.
\end{abstract}

Also, farm size and access to credit also influenced the partial usage of SAP. The major constraints limiting the usage were high cost of fertilizers, high cost of improved seed and unavailability agrochemicals. The study recommends that extension agents should visit local farmers more often and carry out more demonstrations on the usage of SAP.

Keywords: sustainable agriculture; rice farming households; multinomial logit; Kwara State; Nigeria.

\section{INTRODUCTION}

The predominance of crop production in the agricultural sector in Nigeria places it in a pivotal position in issues of sustainable agriculture in Nigeria. As in many developing countries, food production in Nigeria is linked to small scale agriculture. The small scale farmers in this system, which mostly consist of individual households, are responsible

\footnotetext{
${ }^{1}$ Department of Agricultural Economics and Farm Management, University of Ilorin, Kwara State, Nigeria
} 
for a large share of the total agricultural output, land being cultivated and farming population (Brown and Wolf, 2005). The significance of household farmers to sustainable agricultural and rural development is acquired from their dominance of the agricultural sector of the country.

Rice is a cereal crop belonging to the family Gramineae, which is one of man's oldest food item and it is one of the major crops produced in Nigeria. It is the major food for the largest number of people on Earth, and it is eaten by about half of the world's population (GRiSP, 2013). It is the fourth major cereal in Nigeria after sorghum, millet and, maize in terms of output and cultivated land area (Babafada, 2003). Rice is a major staple food and most popular cereal crop of high nutritional value grown and consumed in all ecological zones in the country. Rice being a very high yielding crop, is capable of producing over a hundred bags from an acre of rice farm. All that is required is a very good swampy, less acidic land, high yielding variety of rice seed, proper fertilizer application, a good weed control at the right time and early planting.

As far as rice production is concerned in Nigeria, Kwara State as a comparative advantage (Ministry of Agriculture, Kwara State, 2004), with estimated yield of $2.37 \mathrm{t} / \mathrm{ha}$ of cultivated land. Kwara State is one of the beneficiaries of several governments' intervention programme for rice farming. Therefore, this research work is concerned about the assessment of sustainable agricultural practices and related problems among rice farming households in Kwara State.

The objectives of this study therefore were the following: to examine the sustainable agricultural practices in rice farming; to identify the level of usage of sustainable agricultural practices in rice farming; to assess factors influencing the level of usage of sustainable agricultural practices; to identify the constraints limiting the usage of sustainable agricultural practices.

\section{MATERIAL AND METHODS}

\section{Study area}

This research was carried out in Kwara State, Nigeria (Fig. 1). The State comprise of 16 Administrative local government areas with a population of about 2.37 million people (National Population Census, 2006) and projected in 2012 to be about 2.86 million representing 3.2\% annual growth rate in population and an average density of 88 persons per square kilometer (NPC, 2006; KWADP, 2011). It is located between latitudes $7^{\circ} 45^{\prime} \mathrm{N}$ and $9^{\circ} 30^{\prime} \mathrm{N}$ and longitude $2^{\circ} 30^{\prime} \mathrm{E}$ and $6^{\circ} 25^{\prime} \mathrm{E}$ and a total land area of 3.69 million hectares and about 248000 farming households with majority living in rural areas. The state was divided into four agricultural zones by the Kwara State Agricultural Development Project (KWADP), in consonance with ecological characteristics, cultural practices and project administrative, which are: Zone A: Baruten and Kaima local government areas; Zone B: Edu and Patigi local government areas; Zone C: Ilorin East, 


\section{SUSTAINABLE AGRICULTURAL PRACTICES IN RICE FARMING HOUSEHOLDS}

Ilorin South, Ilorin West, Asa and Moro local government areas; Zone D: Ekiti, Ifelodun, Irepodun, Offa, Oyun, Isin and Oke-Ero local government areas.

\section{Sampling procedure and sampling size}

A four stage sampling procedure was used: the first stage was a purposive sampling of Zone $\mathrm{B}$ from the four agricultural zones in the study area because the zone is known majorly for rice farming; the second stage was a random selection of one of the two local governments from the zone; the third stage was a random selection of six communities from the selected local government area and; the last stage was a random selection of 25 rice farmers from each of the selected communities to obtain a total number of 150 rice farmers. Field survey using questionnaire and focus group discussion sessions (FGD) were used to elicit data from the respondents.

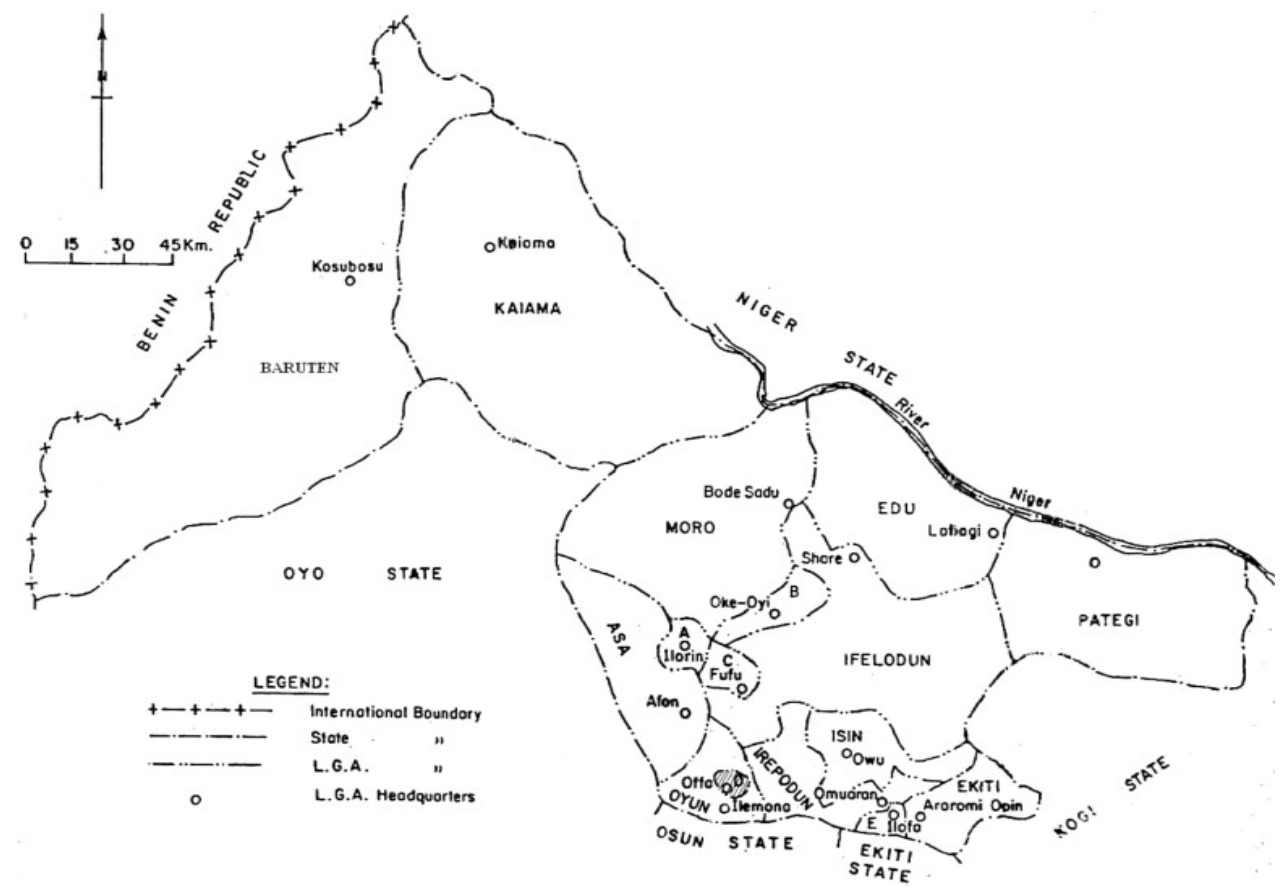

Figure 1 - Map of Kwara State, Nigeria

Source: http://researchgate.net/figure/png

\section{Method of data analysis}

To achieve the study objectives, descriptive statistics comprising the use of percentages, frequency, mean and tabulation was to examine the sustainable agricultural practices in rice farming. To assess factors influencing level of usage of sustainable agricultural practices in rice farming, multinomial logistic regression was employed.

\section{Multinomial logistic regression}

The independent variables could be dichotomous (binary) or continuous (interval or ratio in scale). Multinomial logit, also known as multi-class logistic 
regression, is a simple extension of binary logit which allows for more than two categories of the dependent variables. The model, like binary logit uses maximum likelihood estimation to evaluate the placement of a membership (Croissant, 2011). The multinomial regression model is expressed as:

$$
P i j=\frac{e^{\beta} j^{x} i}{\sum k=j e^{\beta} j^{x} i}
$$

where: $i=1,2, \ldots n$ variable; $k=0,1, \ldots j$ groups; $\beta_{j}=$ vector of parameters that relates $X_{i}$ to the probability of being in group $\mathrm{j}$, where there are $j+i$ groups.

For this study, there are three categories of $Y ; Y=$ probability of adopting the practice. Non-users $=0$; Partial users $=1$; Full users $=2$. The nonusers group was taken as the reference group.

$X_{1}=$ Age (years); $X_{2}=$ Household size (numbers); $X_{3}=$ Farm size (hectares); $X_{4}=$ Level of education (years); $X_{5}=$ Farming experience (years); $X_{6}=$ Number of visits by extension agents in a year; $X_{7}=$ Access to farm credit $($ yes $=1$, no $=0)$; $\mu=$ Error term. The multinomial logit model was therefore used to identify variables that makes households belong to categories 1 (Partial users) and categories 2 (Full users) instead of categories 0 (Non-users).

\section{Likert-type scale}

To examine the constraints limiting the level of usage of sustainable agricultural practices, Likert-type scale was used. The farmers were asked to rate the problems they encountered in the level of usage on a 5 point numerical rating scale of: $5=$ Strongly disagree, $4=$ Disagree, 3 = Undecided, $2=$ Agree, $1=$ Strongly agree. While for the latter, a list of major practices was provided based on the level of usage on a 4 point numerical rating scale: $4=$ Always, $3=$ Sometimes, $2=$ Rarely, $1=$ Never . Rice farmers were expected to tick against each listed according to the degree of severity. The total scores of rice farmers were then calculated as follows:

$$
\text { Mean Score }(M S)=\frac{\text { total score of each problem }}{\text { total number of respondents }}
$$

Mean score was obtained as total scores of each problem statement divided by total number of rice farmers.

\section{RESULTS AND DISCUSSION}

Table 1 presents the result for the information on sustainable agricultural practices in rice farming. The result shows that all the respondents in the study area claimed they are aware of the high yielding varieties seed. The high percentages recorded for awareness of the high yielding varieties information is traceable to its importance in rice production. The major source of awareness to the respondents is from family and friends, in which 55.3\% agreed to this, $32.7 \%$ claimed their source is from extension agents, while a little portion claimed they get theirs from mass media (8\%) and sales agents (4\%). The respondents however have divided opinion about use of improved seed, such that $48 \%$ claimed they use it, while $52 \%$ claimed they sometimes make use of it. The main reason for for non-usage was due to the high cost of improved seeds. This shows most of the respondents do not frequently make 


\section{SUSTAINABLE AGRICULTURAL PRACTICES IN RICE FARMING HOUSEHOLDS}

use of this high yielding seeds because of the high prices.

The result in the Table 1 suggests that most of the respondents have been using sustainable high yielding varieties within the last 10 years, while $22 \%$ started using it over 10 years. The respondents claimed that the main motivator for the use of HYVs is friends and family. This relates to the findings of Babafada (2003), who concluded that farmers are mostly influenced by their fellow farmers and family in the use of HYV seeds. It was also shown that the type of seed varieties used the most by the respondents is Nerica, in which $68.7 \%$ claimed they use it.

Other seeds used by the rice farmers include Faro 44 (Sippi rice), ITA 150 among many others. This implies that majority of the respondents mostly make use of the New Rice for Africa because of its high tolerance to drought, pest resistance, high growth with low water uptake among many others.

The type of pesticides mostly used by the respondents is Best action and Action 40 and most of them use between 0.6-1 litres per application. The respondents mostly use Knapsack Sprayer and Spraying Can to apply pesticides on their farm. And lastly, only $24.0 \%$ of the respondents make use of irrigation channels in rice farming. This implies that majority of the respondents do not make use of irrigation channels, probably due to the fact that make use of Nerica, which has high growth with low water intake.
The information on the level of usage of sustainable agricultural practices in rice farming was displayed in Table 2. It shows that the most used sustainable agricultural practices among rice farming households is the usage of Basal fertilizer application with a mean of 3.12 , applied by broadcasting three weeks after sowing. Best action or Upper colt at the rate of 1 litre/ha to control sucking bugs and grasshoppers has a mean of 3.09, which indicates that this practice is commonly used in the study area. Furthermore, top dress urea application is also commonly practiced by rice farming households in Kwara State, which is mostly applied before panicle initiation. Lowland rice is also a common agricultural practice in the area of study. The result displayed in Table 2 also shows that many of the respondents rarely adopt the usage of fungicides, usage of irrigation water, swamp rice and upland rice.

Multinomial regression was used to examine the factors that influence the usage of sustainable agricultural practices in the area of study (Table 3). The result showed that there are no significant factors that influence the non-usage of sustainable agricultural practices.

However, farm size and access to credit were found to significantly influence the partial usage of sustainable agricultural practices. This correlates with the result of Mariano (2012) and Kudi et al. (2010). 


\section{K.K. OSASONA, G.B. AKINSOLA , M.F. SALAMI, L.O. ADEBISI, O.A. ADEBISI, O. FASHOLA}

Table 1 - Information on sustainable agricultural practices in rice farming

\begin{tabular}{|c|c|c|}
\hline \multicolumn{3}{|c|}{ Awareness of high yielding varieties seed } \\
\hline Aware & 150 & 100.0 \\
\hline Unaware & 0 & 0.0 \\
\hline \multicolumn{3}{|l|}{ Sources of awareness } \\
\hline Family and friends & 83 & 55.3 \\
\hline Extension agent & 49 & 32.7 \\
\hline Mass media & 12 & 8.0 \\
\hline Seed sales agent & 6 & 4.0 \\
\hline \multicolumn{3}{|c|}{ Usage of improved seeds } \\
\hline Yes & 72 & 48.0 \\
\hline No & 0 & 0.0 \\
\hline Sometimes & 78 & 52.0 \\
\hline \multicolumn{3}{|c|}{ Year of commencement of usage } \\
\hline $2001-2008$ & 33 & 22.0 \\
\hline $2009-2016$ & 117 & 78.0 \\
\hline \multicolumn{3}{|c|}{ Source of motivation of usage } \\
\hline Extension worker & 34 & 22.7 \\
\hline Friends and family & 86 & 57.3 \\
\hline Radio & 30 & 20.0 \\
\hline \multicolumn{3}{|c|}{ Reasons responsible for non-usage } \\
\hline Too expensive & 42 & 53.8 \\
\hline Not available in my area & 36 & 46.2 \\
\hline \multicolumn{3}{|c|}{ Type of improved seed varieties usage } \\
\hline Nerica & 103 & 68.7 \\
\hline Faro 44 (Sippi rice) & 29 & 19.3 \\
\hline ITA 150 & 6 & 4.0 \\
\hline Others & 12 & 8.0 \\
\hline \multicolumn{3}{|l|}{ Type of pesticide } \\
\hline Fungicide & 18 & 12.0 \\
\hline Best action pesticide & 71 & 47.3 \\
\hline Magic force & 6 & 4.0 \\
\hline Action 40 & 26 & 17.3 \\
\hline Lara force & 12 & 8.0 \\
\hline Cyperstop and stinge & 17 & 11.3 \\
\hline \multicolumn{3}{|c|}{ Rate of usage of pesticide (litres/ha) } \\
\hline$\geq 0.5$ & 39 & 26.0 \\
\hline$\leq 0.6$ & 111 & 74.0 \\
\hline \multicolumn{3}{|c|}{ Mode of application of pesticide } \\
\hline Knapsack Sprayer & 86 & 57.3 \\
\hline Spraying can & 64 & 42.7 \\
\hline \multicolumn{3}{|c|}{ Usage of irrigation channel } \\
\hline No & 114 & 76.0 \\
\hline Yes & 36 & 24.0 \\
\hline
\end{tabular}

Source: Field survey (2019) 


\section{SUSTAINABLE AGRICULTURAL PRACTICES IN RICE FARMING HOUSEHOLDS}

Table 2 - Information on the level of usage of sustainable agricultural practices in rice farming

\begin{tabular}{lcccccc}
\hline $\begin{array}{l}\text { Sustainable } \\
\text { agricultural } \\
\text { practice }\end{array}$ & Always & Sometimes & Rarely & Never & Mean & Rank \\
\hline $\begin{array}{l}\text { Basal fertilizer } \\
\text { application }\end{array}$ & $84(56 \%)$ & $24(16.0 \%)$ & $18(12.0 \%)$ & $24(16 \%)$ & 3.12 & $1^{\text {st }}$ \\
\hline $\begin{array}{l}\text { Use of best } \\
\text { actions } \\
\text { pesticide }\end{array}$ & $85(56.7 \%)$ & $23(15.3 \%)$ & $12(8.0 \%)$ & $30(20 \%)$ & 3.09 & $2^{\text {nd }}$ \\
\hline $\begin{array}{l}\text { Usage of top } \\
\text { dress urea } \\
\text { application }\end{array}$ & $59(39.3 \%)$ & $61(40.7 \%)$ & $6(4.0 \%)$ & $24(16.0 \%)$ & 3.03 & $3^{\text {rd }}$ \\
\hline Lowland rice & $58(38.7 \%)$ & $50(33.3 \%)$ & $12(8.0 \%)$ & $30(20.0 \%)$ & 2.90 & $4^{\text {th }}$ \\
\hline $\begin{array}{l}\text { Usage of } \\
\text { fungicide }\end{array}$ & $29(19.3 \%)$ & $34(22.7 \%)$ & $52(34.7 \%)$ & $35(23.3 \%)$ & 2.43 & $5^{\text {th }}$ \\
\hline $\begin{array}{l}\text { Usage of } \\
\text { irrigation water }\end{array}$ & $58(38.7 \%)$ & $9(6.0 \%)$ & $15(10.0 \%)$ & $68(45.3 \%)$ & 2.38 & $6^{\text {th }}$ \\
\hline Swamp rice & $17(11.3 \%)$ & $45(30.0 \%)$ & $41(27.3 \%)$ & $47(31.3 \%)$ & 2.21 & $7^{\text {th }}$ \\
\hline Upland rice & $12(8.0 \%)$ & $18(2.0 \%)$ & $29(19.3 \%)$ & $91(60.7 \%)$ & 1.67 & $8^{\text {th }}$ \\
\hline
\end{tabular}

Among the full users of SAP, significant factors that influence the full usage of sustainable agricultural practices are farm size, level of education, farming experience, extension contact and access to credit. The variables determine why households prefer to make full use of $\mathrm{SAP}$ in rice farming. In order to measure the significance of the model, the $\log$ likelihood and its ratio were used, which are 382.24 and 0.000, respectively. This indicates that the model is fit at 5\% alpha level. This result is line with the assertions of Muhammad-Lawal et al. (2009); Ogunniyi et al. (2015), Maurice et al. (2015) and Kudi et al. (2010).

Farm size has a positive and significant influence on the usage of SAP, this implies that probability of the household making use of SAP increases as farm size increases. This result is contrary to the findings of
Adenuga et al. (2012) that farm size as a negative coefficient, which implies that farmers with smaller farm size are more likely to use recommended technology, compared to farmers with larger farm size.

Level of education in this study has a significant positive influence on usage of SAP and this result correlates with the assertions of MuhammadLawal et al. (2009) in their findings that a farmer's level of education has a significant positive influence on his ability to adopt agricultural innovations and make decisions on various aspects of farming.

In this study, farming experience has a significant positive influence on SAP usage and this relates with the findings of Oguniyi et al. (2015) that experience has a positive and significant relationship with technical efficiency. This implies that experienced farmers are more 
technically efficient than inexperienced farmers.

Extension contact in this study has a significant negative influence on SAP usage. This implies that has number of contact with extension agent in a year decrease, it decreases the probability of households usage of SAP. This relates to the findings of Maurice et al. (2015) that increase in extension services to farmers tend to decrease technical inefficiency in food crop production. Also, access to credit has a significant positive influence on usage of SAP, and this relates with the findings of Kudi et al. (2010) that farmers will adopt new innovations if they have access to credit, which will enable them to purchase inputs and pay for labor required.

Table 3 - Factors influencing level of usage of sustainable agricultural practices

\begin{tabular}{|c|c|c|c|}
\hline \multirow{2}{*}{ Variables } & Non-users & Partial users & Full users \\
\hline & Parameter & Parameter & Parameter \\
\hline Intercept & $157.47(0.342)$ & $-38.11(0.844)$ & $93.27(0.919)$ \\
\hline Age & $-117.73(0.416)$ & $-71 . .054(0.695)$ & $-24.24(0.973)$ \\
\hline Household size & $-68.33(0.219)$ & $174.18(0.143)$ & $-42.39(0.142)$ \\
\hline Farm size & $37.22(0.07)$ & $102.53(0.042)^{*}$ & $126.36(0.011)^{*}$ \\
\hline Level of education & $-2.755(0.594)$ & $15.702(0.279)$ & $52.60(0.000)^{* *}$ \\
\hline $\begin{array}{l}\text { Farming } \\
\text { experience }\end{array}$ & $7.718(0.553)$ & $-36.12(0.55)$ & $2.178(0.000)^{* *}$ \\
\hline Extension contact & 16.662(0.999) & $14.675(0.999)$ & $-8.694(0.000)^{\star * *}$ \\
\hline Access to credit & $-47.526(0.406)$ & $16.864(0.000)^{* *}$ & $13.44(0.012)^{*}$ \\
\hline Log likelihood & $382.24^{* \pi}$ & & \\
\hline Likelihood ratio & 0.000 & & \\
\hline
\end{tabular}

Source: Field survey (2019)

Note: Figures in brackets are the t-value of the estimated coefficients; ${ }^{*}$ implies $5 \%$ significance and ${ }^{* *}$ imply significance at $1 \%$.

Constraints faced by the respondents in the adoption of sustainable agricultural practices was displayed in Table 4. It shows that the most severe constraints faced by the respondents is high cost of fertilizer, such that $64.7 \%$ of the respondents strongly agreed, $15.3 \%$ agreed, $8.0 \%$ were undecided, $4.0 \%$ disagreed and $8.0 \%$ strongly disagreed. The mean of the response is 4.25 , which indicate that the respondents face inadequate supply of fertilizers. The respondents also face high cost of improved variety of seeds, high cost of agro- chemicals, non-availability of credits, high cost of irrigations water, marketing problems, high incidence of pest and disease infestation, ineffective extension service/poor extension agent farmers contacts and inadequate knowledge of modern technology on rice production. Less impactful constraints faced by the respondents are climate change and poor interest in rice production. This result shows that the respondents of the study face various challenges, such that most of the respondents agreed to the statements. This 


\section{SUSTAINABLE AGRICULTURAL PRACTICES IN RICE FARMING HOUSEHOLDS}

conforms to the findings of Osiname (2002) and that of AgroNigeria (2014), in which they asserted that rice farmers in Nigeria encounter various difficulties.

Table 4 - Constraint associated with the usage of sustainable agricultural practices by rice farmers

\begin{tabular}{|c|c|c|c|c|c|c|c|}
\hline Constraints & $\begin{array}{l}\text { Strongly } \\
\text { agree }\end{array}$ & Agree & $\begin{array}{l}\text { Unde- } \\
\text { cided }\end{array}$ & $\begin{array}{l}\text { Disa- } \\
\text { gree }\end{array}$ & $\begin{array}{l}\text { Strongly } \\
\text { disagree }\end{array}$ & Mean & Rank \\
\hline $\begin{array}{l}\text { High cost of } \\
\text { fertilizers }\end{array}$ & $\begin{array}{l}97 \\
(64.7 \%) \\
\end{array}$ & $\begin{array}{l}23 \\
(15.3 \%) \\
\end{array}$ & $\begin{array}{l}12 \\
(8.0 \%)\end{array}$ & $\begin{array}{l}6 \\
(4.0 \%)\end{array}$ & $12(8.0 \%)$ & 4.25 & $1^{\text {st }}$ \\
\hline $\begin{array}{l}\text { High cost of } \\
\text { improved variety of } \\
\text { seed }\end{array}$ & $84(56 \%)$ & $\begin{array}{l}24 \\
(16 \%)\end{array}$ & $\begin{array}{l}12 \\
(8.0 \%)\end{array}$ & $\begin{array}{l}12 \\
(8.0 \%)\end{array}$ & $\begin{array}{l}18 \\
(12.0 \%)\end{array}$ & 3.96 & $2^{\text {nd }}$ \\
\hline $\begin{array}{l}\text { High cost of agro } \\
\text { chemicals }\end{array}$ & $\begin{array}{l}64 \\
(42.7 \%)\end{array}$ & $\begin{array}{l}44 \\
(29.3 \%) \\
\end{array}$ & $\begin{array}{l}24 \\
(16.0 \%)\end{array}$ & $\begin{array}{l}6 \\
(4.0 \%)\end{array}$ & $12(8.0 \%)$ & 3.95 & $3^{\text {rd }}$ \\
\hline $\begin{array}{l}\text { Non availability of } \\
\text { credits }\end{array}$ & $81(54 \%)$ & $\begin{array}{l}21 \\
(14 \%)\end{array}$ & $\begin{array}{l}15 \\
(10 \%)\end{array}$ & $\begin{array}{l}10 \\
(6.7 \%) \\
\end{array}$ & $\begin{array}{l}23 \\
(15.3 \%) \\
\end{array}$ & 3.85 & $4^{\text {th }}$ \\
\hline $\begin{array}{l}\text { High cost of } \\
\text { irrigations water }\end{array}$ & $\begin{array}{l}62 \\
(41.3 \%)\end{array}$ & $\begin{array}{l}29 \\
(19.3 \%)\end{array}$ & $\begin{array}{l}24 \\
(16.0 \%)\end{array}$ & $\begin{array}{l}6 \\
(4.0 \%)\end{array}$ & $\begin{array}{l}29 \\
(19.3 \%)\end{array}$ & 3.60 & $5^{\text {th }}$ \\
\hline Marketing problems & $\begin{array}{l}35 \\
(23.3 \%) \\
\end{array}$ & $\begin{array}{l}51 \\
(34.0 \%) \\
\end{array}$ & $\begin{array}{l}18 \\
(12.0 \%) \\
\end{array}$ & $\begin{array}{l}23 \\
(15.3 \%) \\
\end{array}$ & $\begin{array}{l}23 \\
(15.3 \%) \\
\end{array}$ & 3.35 & $6^{\text {th }}$ \\
\hline $\begin{array}{l}\text { Problems } \\
\text { associated with } \\
\text { implementation of } \\
\text { rice }\end{array}$ & $\begin{array}{l}47 \\
(31.3 \%)\end{array}$ & $\begin{array}{l}29 \\
(19.3 \%)\end{array}$ & $\begin{array}{l}17 \\
(11.3 \%)\end{array}$ & $\begin{array}{l}12 \\
(8.0 \%)\end{array}$ & $\begin{array}{l}45 \\
(30.0 \%)\end{array}$ & 3.14 & $7^{\text {th }}$ \\
\hline $\begin{array}{l}\text { High incidence of } \\
\text { pest and diseases } \\
\text { infestation }\end{array}$ & $\begin{array}{l}12 \\
(8.0 \%)\end{array}$ & $\begin{array}{l}73 \\
(48.7 \%)\end{array}$ & $\begin{array}{l}12 \\
(8.0 \%)\end{array}$ & $\begin{array}{l}23 \\
(15.3 \%)\end{array}$ & $\begin{array}{l}30 \\
(20.0 \%)\end{array}$ & 3.10 & $8^{\text {th }}$ \\
\hline $\begin{array}{l}\text { Ineffective } \\
\text { extension service/ } \\
\text { Poor extension } \\
\text { agent farmers } \\
\text { contacts }\end{array}$ & $\begin{array}{l}52 \\
(34.7 \%)\end{array}$ & $\begin{array}{l}15 \\
(10.0 \%)\end{array}$ & $\begin{array}{l}12 \\
(8.0 \%)\end{array}$ & $\begin{array}{l}34 \\
(22.7 \%)\end{array}$ & $\begin{array}{l}37 \\
(24.7 \%)\end{array}$ & 3.07 & $9^{\text {th }}$ \\
\hline $\begin{array}{l}\text { Inadequate } \\
\text { knowledge of } \\
\text { modern tech on rice } \\
\text { production }\end{array}$ & $\begin{array}{l}29 \\
(19.3 \%)\end{array}$ & $\begin{array}{l}18 \\
(12.0 \%)\end{array}$ & $\begin{array}{l}50 \\
(33.3 \%)\end{array}$ & $\begin{array}{l}35 \\
(23.3 \%)\end{array}$ & $\begin{array}{l}18 \\
(12.0 \%)\end{array}$ & 3.03 & $10^{\text {th }}$ \\
\hline Climate change & $\begin{array}{l}24 \\
(16.0 \%) \\
\end{array}$ & $\begin{array}{l}17 \\
(11.3 \%) \\
\end{array}$ & $\begin{array}{l}18 \\
(12.0 \%) \\
\end{array}$ & $\begin{array}{l}61 \\
(40.7 \%) \\
\end{array}$ & $\begin{array}{l}30 \\
(20.0 \%) \\
\end{array}$ & 2.63 & $11^{\text {th }}$ \\
\hline $\begin{array}{l}\text { Low/Poor interest in } \\
\text { rice production }\end{array}$ & $\begin{array}{l}29 \\
(19.3 \%)\end{array}$ & $\begin{array}{l}12 \\
(8.0 \%)\end{array}$ & $\begin{array}{l}18 \\
(12.0 \%)\end{array}$ & $\begin{array}{l}18 \\
(12.0 \%)\end{array}$ & $\begin{array}{l}73 \\
(48.7 \%)\end{array}$ & 2.37 & $12^{\text {th }}$ \\
\hline
\end{tabular}

Source: Field survey (2019)

\section{CONCLUSION AND RECOMMENDATIONS}

Based on the results of the study, it was revealed that most of the respondents have no access to credit facilities and they barely have contact with extension agents. The multinomial logit regression revealed that farm size and access to credit significantly influenced household's partial usage of sustainable agricultural practices, while farm size, level of education, farming experience, extension contact 
and access to credit significantly influenced household's full usage of sustainable agricultural practices. The farmers in the study area are faced with various constraints, which utters the usage of sustainable agricultural practices, some of which include: inadequate fertilizers, high cost of improved seeds, high cost of agrochemicals among many others.

A major implication of the findings of this study is the need to intensify the provision of extension support services, especially appropriate sustainable agricultural practices, to rice farmers in the study area. Governments should partner with private sectors, particularly the seed-distribution firms, through offering incentives, such as relaxing tariffs on imports of inputs, so as to ensure distribution and supply of HYVs at affordable prices. The significant relationship between access to credit and level of usage of SAP indicates that adoption of SAP increases as farmers' has access to credit. Therefore, since lack of capital was an obstacle to the adoption of SAP, efforts should be made to make credit accessible to farmers. Also, cost of fertilizer should be subsidized, since high cost of fertilizer was a major constraint limiting the usage of SAP.

\section{REFERENCES}

AgroNigeria (2014). Rice farming: what you need to know. Available at: https://www.agronigeria.com.ng

Adenuga, A.H., Omotesho, K.F., Olatinwo, K.B., Muhammad-Lawal, A. \& Fatoba, I. (2012). Determinants of fertilizer usage in dry season Amaranthus vegetable production in Kwara State, Nigeria, Agrosearch, 12 (2): 126-134, DOI: 10.4314/ agrosh.v12i2.2

Babafada, M. (2003). Integrated rice production and export in Nigeria, Paper presented at a Seminar on Sustainable Rice Production in Nigeria, Organized by Central Bank of Nigeria, Kaduna, Jan. 14-15, pp. 1-11.

Brown, L.R. \& Wolf, E.C. (2005). Reversing Africa decline. World Watch Courier (June). Environmental and Development, No. 87.

Croissant, Y. (2011). Mlogit: multinomial logistic regression model. Available at http://cran.r-project.org/ package/ mlogit

GRiSP (Global Rice Science Partnership) (2013). Rice almanac: Source book for one of the most important economic activities on Earth (4 ${ }^{\text {th }}$ edition). AgEcon Search, Retrieved from http://ageconsearch. umn.edu//handle/16448

Kwara Agricultural Development Project (2011). Annual Report, July, 2011.

Kudi, T.M., Bolaji, M., Akinola, M.O. \& Nasa, I.D.H. (2010). Analysis of adoption of improved maize varieties among farmers in Kwara State, Nigeria. Int. Peace Dev.Stud., 1(3): 8-12.

Maurice, D.C., Joseph, M. \& Garba, A. (2015). Analysis of technical Inefficiency in food crop production systems among small-scale farmers in some selected local government areas of Adamawa State, Nigeria. ATBU Journal of Science, Technology and Education, 3(1): 1-14.

Mariano, M.J., Villano, R. \& Fleming, E. (2012). Factors influencing farmers' adoption of modern rice technologies and good management practices in the Philippines. Agric.Syst., 110: 41-53, DOI: 10.1016/j.agsy.2012.03.010 


\section{SUSTAINABLE AGRICULTURAL PRACTICES IN RICE FARMING HOUSEHOLDS}

Ministry of Agriculture, Kwara State of Nigeria (2004). Development and investment policies in agriculture, April 2003/2004 Edition.

Muhammed-Lawal, A., Omotesho, O.A. \& Falola, A. (2009). Technical efficiency of youth participation in agriculture: a case study of the youth in agriculture programme in Ondo State, South Western Nigeria. Nigerian J.Agric. Food Environ., 5(1): 20-26.

NPC (National Population Commission) (2006). Nigerian population census report 2006.
Ogunniyi, L.T., Oluwafemi, Z.O \& Adepoju, A.A (2015). Mini-livestock marming as a strategy for food security in Oyo State of Nigeria. Journal of Agriculture and Sustainability, 7(2): 171-186.

Osiname, O.A. (2002). Review of current status, policy and prospects of rice production in Nigeria. Paper presented at the Rice Stakeholders Workshop. Nigerian Institute of Social and Economic Research, $19^{\text {th }}-20^{\text {th }}$ November. 